\title{
Potential Benefits of Ambergris Beyond Perfume
}

\author{
Prashant Kumar Singh, Badruddeen*, Mohammad Irfan Khan, Mohammad Khalid and Ghazanfer \\ Department of Pharmacology, Integral University, India
}

Submission: May 21, 2018; Published: August 21, 2018

*Corresponding author: Badruddeen, Department of Pharmacology, Faculty of Pharmacy, Integral University, Kursi Road, Lucknow-226026, India, Tel: +91-9918196188; Email: badarmiracle@gmail.com

\begin{abstract}
The aim of this review is to highlight the biological source, chemistry, traditional uses, pharmacological effects and traditional formulations of ambergris. It is a solid waxy disagreeable odorous substance obtained from sperm whale. Ambergris is used to make perfume. Chemically it contains ambrein, ambroxan, ambrinol, and ambroxide. It is traditional used in treating general weakness, epilepsy, typhoid, fever, hysteria and other nervous disorders or afflictions. Its pharmacological activities are reported as cytotoxic, aphrodisiac, anti-diabetic and antinociceptive activity. There number of Indian traditional formulations is available for above treatment. There are further studies and clinical trials should be conducted to support its therapeutic uses.
\end{abstract}

Keywords: Ambergris; Pharmacological effects; Nervous disorders or afflictions; Antinociceptive activity; Cytotoxic; Sperm whale

\section{Introduction}

Ambergris is a solid waxy substance originating in the intestine of the sperm whale (Physeter macrocephalus). Whales excrete it through the mouth when it is too large to pass through the digestive system. Fresh ambergris is black and soft and has a disagreeable odour. Ambergris is utilized for medicines, potions and as a spice. In Eastern culture and was used to stabilize the odor of acceptable perfumes in the West. Chemically, ambergris contains alkaloids, acids, and a specific compound called ambreine, which is similar to cholesterol [1]. Ambergris is used to make perfume as it has a smell similar to musk. Ambergris has been used for many years in the perfume and medical industries to fix the odours of scents [2]. Paulus Aegineta described that it was made recognized to pharmacy by the Arabs as ambar in other bordering countries [3]. References to ambar as a perfume are mentioned only in Sanskrit or Prakrit literature [4]. Ambergris is cited in a different way in Indian and other languages: - Sanskrit - ambara, Hindi - amber, sugandh; Konkani - amber; Gujarathi - ambara; Tamil - minumbar; Arabic - amber; Persian - musk amber; Singalese - mus sumbra; Burmese - payan-anbhat; and so on [5].

\section{Chemical Properties and Compositions}

Ambergris is comparatively non-reactive to acid. Ambrein (C30H520) is white crystals of a terpene, is separated from ambergris by heating raw ambergris in alcohol, then permitting the resulting solution to cool. Breakdown of the relatively scentless ambrein through oxidation produces ambroxan and ambrinol, the main odor components of ambergris. Ambroxide ( $\mathrm{C} 16 \mathrm{H} 280)$ is identified by the brand name Ambroxan, is a naturally arising terpenoid and one of the chief constituent responsible for the odor of ambergris. Ambroxan is an autoxidation product of ambrein and is used in perfumery for producing ambergris notes and as a fixative [6].

\section{Traditional Uses}

From early days, ambergris was a cherished material in the East as a perfume and drug. It was utilized and suggested by medieval apothecaries for its healing powers and the perfumers for its scent. White law Ainslie (1826), has mentioned in "In Hindoostan" Ambergris is primarily utilized as a scent; a drop or two of the spirit mixed with a huge quantity of lavender water, accounting much to its fragrance". The Indian Materia medica listed this wonderful substance as a stimulant and antispasmodic; it is used in treating general weakness, epilepsy, typhoid, fever, hysteria and other nervous disorders or afflictions, by the practitioners of the Ayurveda and Unani systems of medicine, in combination with other medicinal herbs to treat the above-said ailments [7].

\section{Pharmacological Activities}

\section{Cytotoxic activity}

The ambergris exhibits cytotoxic activities against human liver carcinoma, colon adenocarcinoma, lung carcinoma and human breast adenocarcinoma cell lines. The anti-inflammatory activities in terms of the inhibition of human neutrophil function were also evaluated for ambrein [8].

\section{Effect on Hormonal activity}

Studies have exposed the encouraging effects of Agnijvar (ambergris) in both sexual desire and body weights owing to its 
influence on some endocrine hormones. There was substantial rise in testosterone, estradiol, prolactin, insulin, cortisol, thyroxin (T4) levels and body weights after ambergis administration [9].

\section{Aphrodisiac activity}

Ambrein, a major constituent of ambergris has supportive activity on masculine sexual ability on rats. The copulatory studies were conducted by caging males with receptive females. After observation the copulatory behavior of treated male rats, ambrein formed repeated incidents of penile erection, a dosedependent, strong and repetitive rise in intromissions and an amplified anogenital investigatory performance $[10,11]$. This study has been proven to increase sexual behavior in rats, which providing some support for its traditional aphrodisiac use.

\section{Anti-diabetic activity}

Ambrein reduces the blood glucose level of normal and moderately alloxan treated diabetic rats by enhancing glucose utilization. Ambrein did not reduce the hyperglycemia of glucose loaded rats in the presence of mannoheptulose but it reduced the hyperglycemia of glucose-loades rats in the absence of mannoheptulose [12].

\section{Analgesic and antinociceptive activity}

Ambrein have been shown to act as an analgesic by reducing thermal sensitivity or nociceptive sensitivity in rodents [13].

\section{Indian Traditional Formulations and their uses}

There are number of formulations which are traditionally used in Indian traditional system of medicine such as Habbe Ambar Momyai which is used as cardiotonic, nervine tonic, aphrodisiac and removes the weakness of noble organs; Habbe Nishat used as brain tonic, cardiotonic and is beneficial in sexual disability; Majoon Piyaz used as aphrodisiac and strengthens the kidneys; Habbe Jadwar used as aphrodisiac, strengthens the brain and in premature ejaculation [14,15]; Khamira Abresham Sheera Unnab Wala used in the treatment of tuberculosis, dry cough, debility, anxiety, palpitation and weakness of eyesight; Majoon Mumsik Muqavvi helps to treat impotency, sexual debility, premature ejaculation [16]; Khameera Abresham Hakim Arshad walais beneficial in Amraz Qalb (Cardiac Ailments), Khafqan (Palpitation), Malekholia (Melancholia) and Nazla (Catarrh) in summer. It is used as Muqavvi Jiger (Liver tonic), Muqavvi Qalb (Heart tonic), Muqavvi Dimagh (Brain tonic) and Muqavvi Aaza Raisa (Vital organ tonic); Khameera Gaozaban Ambari used as Muqavvi Hafiza (Memory enhancer) and is also beneficial in palpitation [17].

\section{Conclusion}

From this review, many of its medicinal properties, traditional uses and chemical properties have been observed. Although Ambergis has been used successfully in Ayurvedic/ Unani system of medicine for centuries, further studies and clinical trials should be conducted to support its therapeutic use. It may also give potentiating effect when given in combination with other herbs or drugs.

\section{References}

1. https://www.britannica.com/science/ambergris

2. https://www.environment.gov.au/marine/marine-species/ cetaceans/ambergris

3. Gode PK (1945) History of Ambergris in India between about A.D. 700 and 1900. Journal of the University of Bombay, pp. 44-45.

4. Gode PK (1949) History of Ambergris in India between about A.D. 700 and 1900, CHEMIA: Annual Studies in the History of Chemistry 2: 5155.

5. Nanda KM (1926) Indian Materia Medica, Bombay, p. 1072.

6. Karl-Georg Fahlbusch, et al. (2007) Flavors and Fragrances. Ullmann's Encyclopedia of Industrial Chemistry (7th ed.) 72.

7. Ainslie, Whitelaw, Materia Indica, Vol. I, London, 1826, Ch. Ix.

8. Shen, Ya-Ching, et al. (2007) Chemical transformation and biological activities of ambrein, a major product of ambergris from Physeter macrocephalus (Sperm Whale). J Nat Prod 70(2): 147-53.

9. Kotb-el-sayed MI, Al-shoaibi ZY (2012) Effects of Ambergris on appetite and serum endocrine hormonal levels in skinny sufferers. Asian J Pharm Clin Res 5(3): 138-142.

10. Taha SA, Islam MW, Ageel AM (1995) Effect of ambrein, a major constituent of ambergris on masculine sexual behavior in rats. Archives internationals de pharmacodynamie et de therapie 329(2):383-394.

11. Sandroni P (2001) Aphrodisiacs past and present: a historical review. Clinical Autonomic Research 11(5): 303-307.

12. Taha SA (1991) Effect of ambrein on blood glucose levels of rats. J Ethnopharmacol 35(2): 145-48.

13. Taha SA (1992) Studies on the mode of action of ambrein as a new antinociceptive compound. Japanese Journal of Pharmacology $60(2): 67-71$.

14. Essential Oils 1995-2000, Dr Brian M Lawrence, ISBN 0-931710-94-4.

15. www.rexremedies.com/male.html

16. https://www.madanapalas.com/advanced_search_result. php?search_in_description=1\&inc_subcat=1\&keywords=Rex\%20 Remedies\&osCsid=sce6oigs2q31nro7or7ne5ejn6.

17. Kabir Dr, Hifzul (2003) Shamsher's Morakkabat (Unani Formulations). Published by Shamsher Publisher and Distributors, Ist Edition, pp. 8392. 
This work is licensed under Creative Commons Attribution 4.0 License

DOI: 10.19080/JCMAH.2018.07.555705

\section{Your next submission with Juniper Publishers will reach you the below assets}

- Quality Editorial service

- Swift Peer Review

- Reprints availability

- E-prints Service

- Manuscript Podcast for convenient understanding

- Global attainment for your research

- Manuscript accessibility in different formats

(Pdf, E-pub, Full Text, Audio)

- Unceasing customer service

Track the below URL for one-step submission https://juniperpublishers.com/online-submission.php 